Annals of the „Constantin Brâncuşi” University of Târgu Jiu, Economy Series, Issue 3/2012

\title{
THE COMPETITION POLICY IN THE EUROPEAN UNION
}

Lecturer drd. Dumitriţa Florea (Ionescu),

University "Ştefan cel Mare" of Suceava,România, dumitritai@seap.usv.ro

Lecturer drd. Ciprian Ungureanu,

University”Ştefan cel Mare” Suceava, România,

ciprianu@seap.usv.ro

\begin{abstract}
The idea of European unity dates back to antiquity, the time when the Roman Empire also pursued such a goal. Attempts to unify European countries have appeared constantly in history, but their successful culmination crystallized only after the Second World War.

Basically, the two wars have led to the downfall of Europe and the loss of its centenary political and military position. The experience of these wars has led the states to initiate a defense mechanism of peace, security and international cooperation - resulted in creating an organization of universal jurisdiction -The League of Nations. However, the successor of this organization, The United Nations - was one that managed thorough its collective security system represented by the Security Council, to ensure and maintain universal / global peace until now (Stelian Scăunaş, 2005).

The creation of the European Union is based on four founding treaties: The Treaty establishing The European Coal and Steel Community (ECSC) - adopted in Paris on April 18, 1951, entered into force in 1952 - treaty concluded for a period of 50 years and that has terminated in 2002, The Treaty establishing the European Economic Community (EEC,) The Treaty establishing the European Atomic Energy Community (EAEC or EURATOM), both signed in Rome on March 25, 1947 and entered into force in 1958 as the Treaties of Rome, and The Treaty on the European Union, which was adopted at Maastricht on 7th of February 1992 and entered into force in 1993. To these institution treaties we can add the modifying treaties of the founding treaties, including: The Merger Treaty - adopted in Brussels on 8 April 1965, entered into force in 1967; The Single European Act - signed in Luxembourg and Hague in 1986, entered into force in 1987; The Amsterdam Treaty - signed on October 2, 1997, entered into force in 1999, The Treaty of Nice - signed on February 26, 2001, entered into force in 2003, The Lisbon Treaty signed in 2007 and entered into force on December 1st 2009.

The economic development of each community country, of the European Union as a whole is unthinkable without maintaining a functioning competitive environment, fundamental requirement in the market economy. Moreover, competition is considered as the most important cause of economic and scientific-technical progress.

The purpose of the present work is the elucidation of the specific notions attached to competition, competition policy, give-away of the types of competition and the analyze of the existent policies in the domain of the competition.

Leaving from the hypothesis off the specialty literature (reminding here: Ioan Alexandru and the co-workers, Aurelia Cotutin, Dumitru Mazilu, Tudorel Ştefan, Beatrice Grigoriu), such as the relationships which it's proceed between the participants on the same market with the intention to accomplish some personal concerns by the conditions of economic liberty, we try to analyze each type of competition, the competition policies, following concomitantly the achievements of the specific nature of the policy in the domain of competition.

The question which it's shape is if the process of the European integration it's manage to generate an competition policy materialized in a necessary condition for the existence of the unique internal market.

Another problem tackle in this paper-work is the evolution of the competition policy in the European Union bringing close-up the mains international documents which is settle the competition and those evolution in time. As well, an important bearing represent the European institution which administrate the competition policy, an aspect which is debate in the section 3 of this scientific demarche.
\end{abstract} institutions.

Key words: competition, competition politics, trade practices, competition law, european JEL Qualification: K29, K33

„ACADEMICA BRÂNCUŞI” PUBLISHER, ISSN 1844 - 7007 


\section{Definition of the concepts of competition and competition policy}

We can not start our approach without first clarifying the terms "competition" and "competition policy". Competition means pursuing those relationships between all participants from the same market in order to achieve their own interests in terms of economic freedom. Competition can be seen as a reality, a struggle with the economic means, means including quantity, quality and price and extra-economic means, and here we refer to industrial espionage, sabotage actions, dumping policies. In other words, competition can be compared to a confrontation between the operators to achieve better conditions of production, sales, money operations or other economic activities, to obtain as many benefits.

The economic theory of competition identifies the following types of competition: * perfect and imperfect - in this category we have: monopoly, oligopoly and monopolistic competition;

* direct - arises when the competing market players are addressing to the same needs, with similar or identical products;

* indirect - occurs when different goods are offered to meet the same needs; * loyal (fair) - appears when the competition instruments are used properly; * unfair - occurs when unfair means are used to monopolize the market [1].

Gradually, competition has acquired the status of the most important organizational principle of the market economy. This role can only be performed by the perfect competition, which is defined as an environment in which many smaller companies compete to provide a single product and no company can affect prices and trading conditions. The imperfect competition (that is monopoly or oligopoly) appears as a barrier to the market access. Perfect competition requires optimal use of resources, while monopoly is the generator of inefficiency. One of the promoters of free market, Adam Smith believed that the perfect competition is only an abstract concept that can not be found in its pure form in the real economy.

Competition policies allow the development of a regulatory framework in which governments can maintain and enhance competition by increasing the economic performance. A competition policy is absolutely necessary because the private operators and the public authorities may have behaviors that damage the competitive environment for several reasons using various mechanisms and measures.

The competition policy refers to certain laws and actions taken and imposed by governments or by the community as a whole, to eliminate or to discourage certain restrictive business practices applied by certain market participants: cartels, monopolies, non-tariff barriers, etc., which would have the effect of preventing, restricting or distorting competition. The competition policy aims to implement a system that allows a non-distorted competition within an economic area. In the liberal economic theory, the competition policy aims to achieve markets with a perfect competition and to prevent monopolies and oligopolies formation which impose prices to the detriment of consumers.

The competition policy may operate with means that might have, at first sight, a negative role because they are designed to restrict and stop certain actions, to limit the use of practices which may have a negative impact on consumption.

The competition policy aims carrying out the following objectives: a) the increase the consumers' welfare by improving the economic performance; b) the consumer's protection, that is their defense against the tendencies of the large companies to seize markets and set prices for monopoly;

c) stopping the income redistribution in favor of monopolies and cartels;

d) protecting the small and medium enterprises;

e) the integration of the national markets into a single market of the European community.

The process of European economic integration has been accompanied by the ongoing promotion of a common competition policy. After nearly five decades of activity of the European Union this policy is a necessary condition for the existence of the single internal market which assures the free movement of goods, services, capital and labor.

In the European Union, the main beneficiary of a policy of free competition is the citizen as: consumer, participant in the labor market and shareholder or commercial agent. The competition policy promoted by the European Union is based on the belief that the market 
Annals of the „Constantin Brâncuşi” University of Târgu Jiu, Economy Series, Issue 3/2012

with the perfect and pure competition is the best way to ensure the general welfare. Therefore, the competition policy wants to limit, to control even to forbid the enterprises' behavior that affects the perfect competition.

\section{The stages of development and progress in the EU competition policy}

The European competition policy is based on Article 3 (f) of the Treaty of Rome signed on March 25, 1957 and came into force on January 1, 1958, now Article 3 (g) of The Maastricht Treaty signed in 1992 and entered into force in 1993, which establishes that at the level of the community measures should be taken as in the future "the competition in the Common Market not to be distorted". This Treaty provides the way to meet this condition by applying "the rules of competition" that are contained in the Treaty of Rome in Articles 85-94, and in The Maastricht Treaty in Articles 81-89 [2]. In these articles there is regulated the control that can be exercised by the Commission on anti-competitive arrangements, anticompetitive behavior of monopolies and state enterprises, on state aids etc. These behaviors, subject of the Commission's control are even today, after almost 50 years, the content of EU' s competition policy. Very important in this context is The Lisbon Treaty signed in 2007 and entered into force on 1 December 2009 which brings guarantees and provides more efficiency to the European Union and therefore to its 27 members in the areas of: trade policy, competition policy and maintains and strengthens for the European citizens the four freedoms [3]: the free movement of goods, persons, services and capitals and political, economic and social freedom.

When designing the European Community's competition policy, the situation in this area was the following in the six EU countries:

- Germany was the only EU member with articulated legislation for competition;

- Belgium and Luxembourg did not have legislation in this area; - Netherlands was following the provisions of the Competition Act;

- $\quad$ Italy, the monopolies and the restrictive practices were governed by the Civil Code;

- $\quad$ France had a legislation that governed differently the restrictive practices of companies.

This diversity of the legal provisions has imposed the need to adopt procedural rules that enable the implementation of the treaties in a period of three years. In 1962 the procedural rules were adopted in such a manner as the control to remain supranational and to be exercised by the Commission. The European Commission has managed to create a common competition policy, and at the same time, coordinated, which made competition policy to become a sector policy with supranational character. The Commission's attributions on competition policy are contained in "Regulation 17" that through its centralized application diminished the role of the national authorities [4].

The first years of 21 st century brought new dimensions to the competition policy, especially regarding the issue of fusions and state aids. The most important legal instrument, as previously mentioned in the pages of this study, the Treaty of Lisbon in 2009 which introduces a general classification of the skills, in three categories:

- Exclusive attributions - only EU has the power to legislate in areas such as customs union, common commercial policy or competition;

- Actions to support, coordinate or supplement - in areas such as culture, education or industry, the Union's action is limited to support the actions of the Member States (e.g. through the financial aids);

- Shared attributions - in other areas, such as environment, transport and consumer's protection; the distribution of the power of regulation between the EU and the Member States shall conform to the principle of subordination.

\section{EU institutions governing and managing the competition policy}

The actual administration of the competition policy and its development at the level of the European Union is made by the European Commission and the European Court of Justice. The Council of Ministers and the Parliament's intervention in certain stages of evolution of the competitive process was meant to influence and direct certain measures taken by the Commission.

„ACADEMICA BRÂNCUŞI” PUBLISHER, ISSN 1844 - 7007 
Annals of the „Constantin Brâncuşi” University of Târgu Jiu, Economy Series, Issue 3/2012

The role of the Parliament and the Council of Ministers in the competition policy. For a long period of time, the two institutions had a marginal role in terms of competition policy and that is because the decision-making instruments were administered by the Commission. The concrete way to interfere in the competition policy was to influence the Commission's actions by a special report on the issue of competition. Currently, the Parliament has the opportunity to influence the Commission's activity in two ways:

- annually, the Commission shall submit a report on competition issues that needs to be validated by the Parliament; the competition commissioner is required to present this report in front of the Parliament,

- The Parliament asks questions and wants answers regarding the issue of competition, especially about the different effects that the competition policy has on the groups of interest or economic operators.

Regarding the competition issue the Ministerial Council's role was limited to certain casual regulations and providing frame exceptions. It is estimated that the Council's little involvement can be justified by the fact that in the initial stages the process of centralizing the decisions was not stated. The widening and deepening of the integration brought new tasks for the competition policy, enhancing the Council's attributions regarding competition. Moreover, it was the Commission itself that requested the Parliament and the Council to involve more, especially in terms of legislation, to make the competition policy more transparent.

The Commission's role. The power to prevent the possible abuses in terms of competition belongs to the Commission, which may act independently from the Council of Ministers, although some decisions may be appealed to the Court of Justice. The Commission acts either at its own initiative or following up complaints of the Member States, companies or individuals.

The Commission is the body that establishes the main rules, conducts inquiries and gives the solution to be adopted as granting approvals, establishes the interruption of anticompetitive behavior and applies penalties when necessary. The Commission consists of 24 General Directorates, each responsible for a specific area policy, the competition policy is up to the General Manager IV, although the competition policy is the responsibility of other directorates too.

The Commission works with a notification system where companies that make acquisitions, purchases, or other arrangements must provide details about the business. The commission examines in detail the agreement or the deal and concludes whether or not there is a violation of the Treaty and of the rules of free competition.

The companies found guilty of illegal competitive practices by the Commission can be fined up to $10 \%$ of the turnover from the previous year. If agreements between companies are discovered, suspected of violating the free competition, the Commission has the following possible measures:

a) to declare legal a formal decision, if after the investigations it appears that the deal does not distort free competition;

b) to issue a "comfort letter" to allow operation on the competitive market because there are operations without any significant impact;

c) to accept the operation only if fulfilling certain additional conditions;

d) to declare it illegal.

The role of the European Court of Justice and the Court of First Instance. These institutions are responsible for the legal supervising of the competition rules and applying the competition's regulations. The two institutions create an environment that outlines the committee's rules, since their decisions are compulsory for all Member States, given the primacy of Community law over the national law. The direct actions of the dissatisfied companies with the Commission's treatment involve resorting at the two institutions. In the analysis of various cases submitted to it, ECJ makes decisions that can hardly be invalidated.

As the European economic integration entails, among other, the integration of the national markets and achieving a Single Internal Market, the ECJ has identified the competition policy with the policy for the internal market, thereby giving the Commission more responsibilities. 
Annals of the „Constantin Brâncuşi” University of Târgu Jiu, Economy Series, Issue 3/2012

Because the ECJ was sometimes exceeded by the number of cases that had to be solved The Court of First Instance (CFI) [5] whose purpose is to analyze at first, certain types of procedural actions which would take more time if solved by ECJ.

\section{Objectives of competition policy in the European Union}

The provisions of the Community policy regarding competition have resulted in some certain objectives contained in the Treaty of Rome (Art. 85-94) and the Maastricht Treaty (Art. 81-89), namely: the restrictive business practices, the abuse of dominant power (position); the acquisitions and the fusions, the state aid; the policy on the public sector.

a) The restrictive business practices. In Article 85 of the Treaty of Rome we find the provisions prohibiting the restrictive practices which are considered incompatible with the single market principles, namely: fixing the selling or buying prices or some trading conditions; agreements aiming the limitation or the control of production, of the trade markets or sources of supply; contracts subjected to acceptance by the parties of supplementary obligations which have no connection with these transactions. b) The abuse of dominant power is settled under the provisions of Article 86 of the Treaty of Rome. The dominant position or the market power is the power of a company used to become an obstacle in maintaining an effective competition. The concept of "abuse" should be understood as meaning that not a firm's dominant position is prohibited, but only the prohibited practices of a company with a dominant position, i.e.: charging excessive prices or predatory pricing, refusal to deal with certain beneficiaries, imposition of unfair contracts, limiting production, distribution or technical development, etc.. The difficulty lies in determining the abuse, if any, taking into account only the effects of the company's behavior. In such cases there are no exemptions as for the agreements, the sanction is imposed by the Commission that may apply fines or penalties. An example is the abuse of dominant position of Microsoft, on a certain market for computer programs, for which it was sanctioned by the European Commission with the amount of 497 million euros (Tudorel Ştefan, Beatrice Andreşan-Grigoriu, 2007).

c) The mechanism of acquisitions and fusions. The end of the implementation of the Single Market has produced important changes in terms of competition, which imposed an implementation of a strict control of the acquisitions and fusions, which was not foreseen in the Treaty of Rome, for two reasons: the Treaty is a framework document requiring additional (complementary) legislation to implement the principles contained and the Treaty was based on the idea of economic expansion of the EEC, which requires a large concentration of the economic power.

d)The state aid policy. As the physical barriers, the regulatory and tax barriers to the international trade have been removed, the subsidizing of certain sectors has remained one of the few instruments that lead to the imperfection of free competition and market fragmentation.

e)The public sector policy. Another way the European Commission has proposed to create a competitive environment in Europe is to introduce the principles of fair competition in the state property.

\section{Conclusions}

The competition law refers to the intervention on the market where there are problems with the competitive process. The competition process is worth protecting, as it is essential in an economy affected by globalization and innovation. The competition between companies leads to an efficient market and helps consumers, by the pressure on cost reduction and reward of innovative, industrial or service provider organizations. Although is not directly related to the consumer's protection or the establishment of some standards of trade, both areas benefit from the application of the competition law. To determine correctly the size and the purpose of the Community's competition policy it is essential to understand the economic theory underpinning the work of the Commission and the practice of The European Court of Justice, sometimes an frustrating aspect for the lawyers.

We consider that, in the condition of the global crisis, in their fight for market supremacy, the biggest and the small players should renounce at the dumping policies, to all kind of economic sabotage actions, to monopoly and to co-operate in the spirit of an loyal competition. Also, for to truly come in the support of the citizens, the competition policy of the European Union and the government of the member

„ACADEMICA BRÂNCUŞI” PUBLISHER, ISSN 1844 - 7007 
Annals of the „Constantin Brâncuşi” University of Târgu Jiu, Economy Series, Issue 3/2012

states should centre more to the protection of the smaller and middle firms, to protection of the consumers and on the growth of the welfare of those.

We believe that it should be necessary as the European Union to institute an set of drastically measures for the restrict, control and approbate the firms which infringe through their behavior the conditions of the fair competition, and also of one of the most important principle stipulate by the European law - subsidiary principle - which represent matter-of-fact the allot of an certain degree of independence to the local authorities against central authorities and of an specific abilities which held by the different domains, including by the internal market or economic cohesion, as establish too the Lisbon Treaty sign in 2007 and enter in vigour in 2009.

\section{Endnotes:}

(1) Ioan Alexandru, Mihaela Cărăuşan, Ilie Gorjan, Ivan Vasile Ivanoff, Corneliu Manda, AlinaLivia Nicu, Crina Rădulescu, Cătălin Silviu Săraru, 2007.

(2) Dumitru Mazilu, 2004.

(3) See also: www.europa.eu/lisbon_treaty.

(4) Cotutiu Aurelia, Sabău Georgeta Valeria, 2008.

(5) The Court of First Instance (CFI or CPI) was build in 1988 and it's operate since 1989, occupy oneself with three categories of problems: staff problems, CECO Treaty problems and actions from competition field. CPI has 15 judges which work by panel of 5 judges, the decisions being taken through secret vote. CPI has also the role to verify harshly and neutral the actions of the Commission which it's indicate that the approach of the CFI /CPI differ from The European Court of Justice (CEJ).

\section{Bibliography}

1. Anamaria Groza, [Uniunea Europeană. Drept instituţional, Ed. C.H. Beck, Bucureşti, 2008]

2. Cotutiu Aurelia, Sabău Georgeta Valeria, [Drept roman si comunitar al concurentei, Ed. C.H. Beck, Bucuresti, 2008]

3. Dumitru Mazilu, [Integrarea Europeană. Drept comunitar şi instituţii europene, ediţia a II-a, Ed. Lumina Lex, Bucureşti, 2004]

4. Ioan Alexandru, Mihaela Cărăuşan, Ilie Gorjan, Ivan Vasile Ivanoff, Corneliu Manda, Alina-Livia Nicu, Crina Rădulescu, Cătălin Silviu Săraru, [Dreptul administrativ în Uniunea Europeană. Drept administrativ comparat. Drept administrativ al Uniunii Europene, Ed. Lumina Lex, Bucureşti, 2007]

5. Stelian Scăunaş, [Uniunea Europeană. Construcţie. Instituţii. Drept, Ed. All Beck, Bucureşti, 2005]

6. Tudorel Ştefan, Beatrice Andreşan-Grigoriu, [Drept comunitar, Ed. C.H. Beck, Bucureşti, 2007]

7. www.europa.eu/lisbon_treaty 